\title{
Disappearing Anomaly di Bursa Efek Indonesia
}

\author{
A.A. Rai Niti Darmika Sukawati ${ }^{1}$ \\ Dewa Gede Wirama ${ }^{2}$ \\ 1,2Fakultas Ekonomi dan Bisnis Universitas Udayana, Indonesia \\ *Correspondences : nitids1997@gmail.com
}

\begin{abstract}
ABSTRAK
Tujuan penelitian adalah menganalisis apakah terjadi disappearing anomaly di Bursa Efek Indonesia, khususnya untuk Monday effect dan January effect. Analisis dilakukan dengan membandingkan kedua anomali tersebut pada dua periode, yaitu yahun 2011 hingga 2015 dan tahun 2016 hingga 2020. Penelitian menggunakan sampel perusahaan yang konsisten terdaftar pada Indeks Kompas100 selama periode pengamatan, dengan jumlah sampel yang terdiri atas 42 perusahaan. Teknik analisis yang digunakan adalah uji beda dengan independent sample t-test. Hasil pengujian menunjukan bahwa Monday effect pada periode 2016-2020 secara signifikan lebih rendah dibandingkan dengan Monday effect periode 2011-2015, tetapi tidak terdapat perbedaan January effect yang signifikan pada kedua periode tersebut.
\end{abstract}

Kata Kunci: Disappearing Anomaly; January Effect; Monday Effect.

\section{Disappearing Anomaly on the Indonesia Stock Exchange}

\section{ABSTRACT}

The purpose of this research is to analyze whether there is a disappearing anomaly on the Indonesia Stock Exchange, especially for the Monday effect and January effect. The analysis was carried out by comparing the two anomalies in two periods, namely 2011 to 2015 and 2016 to 2020. The study used a sample of companies that were consistently listed on the Kompas100 Index during the observation period, with a total sample consisting of 42 companies. The analysis technique used is a different test with independent sample t-test. The test results show that the Monday effect in the 2016-2020 period is significantly lower than the Monday effect for the 2011-2015 period, but there is no significant difference in the January effect in the two periods.

Keywords: Disappearing Anomaly; January Effect; Monday Effect.

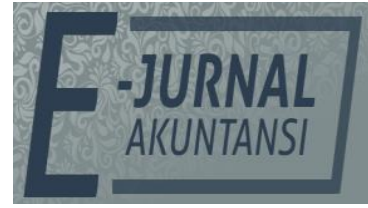

e-ISSN 2302-8556

Vol. 32 No. 2

Denpasar, Februari 2022

Hal. 384-398

DOI:

10.24843/EJA.2022.v32.i02.p08

PENGUTIPAN:

Sukawati, A. A. R. N. D. \& Wirama, D. G. (2022).

Disappearing Anomaly di Bursa Efek Indonesia.

E-Jurnal Akuntansi, 32(2), 384-398

RIWAYAT ARTIKEL:

Artikel Masuk:

11 Januari 2022

Artikel Diterima: 14 Februari 2022

Artikel dapat diakses : https://ojs.unud.ac.id/index.php/Akuntansi/index 


\section{PENDAHULUAN}

Fama (1970) mengemukakan hipotesis pasar efisien dengan menjelaskan keadaan pasar adalah efisien karena harga-harga yang terbentuk di pasar telah mencerminkan secara penuh informasi-informasi yang tersedia. Dalam hipotesis pasar efisien, setiap investor diasumsikan memiliki akses yang sama terhadap informasi, sehingga tidak ada kesempatan memperoleh return abnormal dengan memanfaatkan informasi. Hal ini seringkali diekspresikan sebagai no one can beat the market. Hipotesis pasar efisien mendapatkan reaksi pro dan kontra dari para peneliti di dunia. Salah satu fenomena yang tidak mendukung hipotesis pasar efisien adalah adanya anomali di pasar modal. Anomali pasar dijelaskan sebagai "Techniques or strategies that appear to be contrary to an efficient market". Jika pasar modal benar-benar efisien, anomali seharusnya tidak terjadi secara konsisten. Fenomena ini terlalu luas untuk diabaikan dan terlalu sistemik untuk ditolak sebagai kesalahan semata (Tversky \& Kahneman, 1987).

Di Indonesia, penelitian mengenai anomali secara umum mengungkap terjadi atau tidak terjadinya pada periode tertentu, dan jarang membahas perkembangannya sepanjang periode sehingga sulit mengetahui apakah anomali mengalami penurunan atau tidak. Marquering et al. (2006) menganalisis fenomena disappearing anomalies dengan data pasar modal Amerika Serikat menunjukan anomali telah melemah dan beberapa telah menghilang sepenuhnya. Wong et al. (2006) pada pasar modal Singapura serta Cotter \& McGeever (2018) pada pasar modal Inggris mengungkap hasil analisis serupa mengenai disappearing anomaly. Disappearing anomaly diperkirakan terjadi akibat penurunan pemanfaatan strategi anomali di pasar modal negara maju (Zaremba et al., 2020). Dalam pesatnya perkembangan teknologi di negara maju, asimetri informasi diantara investor telah sangat berkurang dengan berbagai kondisi dan kemajuan, investor diasumsikan menjadi 'canggih' atau dikenal dengan istilah sophisticated investor. Investor yang canggih memahami pola-pola anomali, menganalisis informasi serta strategi investasi alternatif dengan lebih aktif. Salah satu penelitian di Indonesia yang menganalisis perkembangan anomali adalah Sudirman \& Sudirman (2019) yang menemukan fenomena disappearing anomaly atas day of the week effect di indeks IHSG pada pengamatan periode 1990 hingga 2018. Anomali dinyatakan mulai terjadi pada krisis Asia tahun 1998, lalu menghilang pada krisis keuangan global di tahun 2008, kemudian terjadi kembali pada periode setelahnya hingga tahun 2018. Penelitian Wiarta, et al. (2020) pada periode 2010 hingga 2019 mengungkap anomali January effect dengan teknik pengujian yang menggabungkan seluruh data menjadi satu kelompok sehingga tidak menjelaskan evolusi data atau perkembangan anomali selama periode pengamatan.

Penelitian ini menguji dua anomali musiman, yaitu Monday effect dan January effect. Anomali musiman adalah kecenderungan return untuk menampilkan pola pada waktu berhubungan dengan waktu-waktu perdagangan pasar yang terjadi di pasar modal secara berulang. Pemilihan anomali didasarkan pada argumen bahwa January effect dan Monday effect adalah anomali yang paling terlihat jelas pada sebagian besar harga saham dunia (Al-Smadi et al., 2018). Tabel 1 menampilkan ringkasan penelitian terdahulu January effect dan Monday effect untuk memperkirakan evolusi anomali yang terjadi pada pasar modal di Indonesia dalam sepuluh tahun terakhir. Setiap penelitian menggunakan teknik 
yang berbeda-beda, menyebabkan variasi beragam yang berujung pada inkonsistensi hasil penelitian meskipun dalam periode pengamatan yang sama.

Tabel 1. Inkonsistensi Temuan Monday Effect dan January Effect di Indonesia

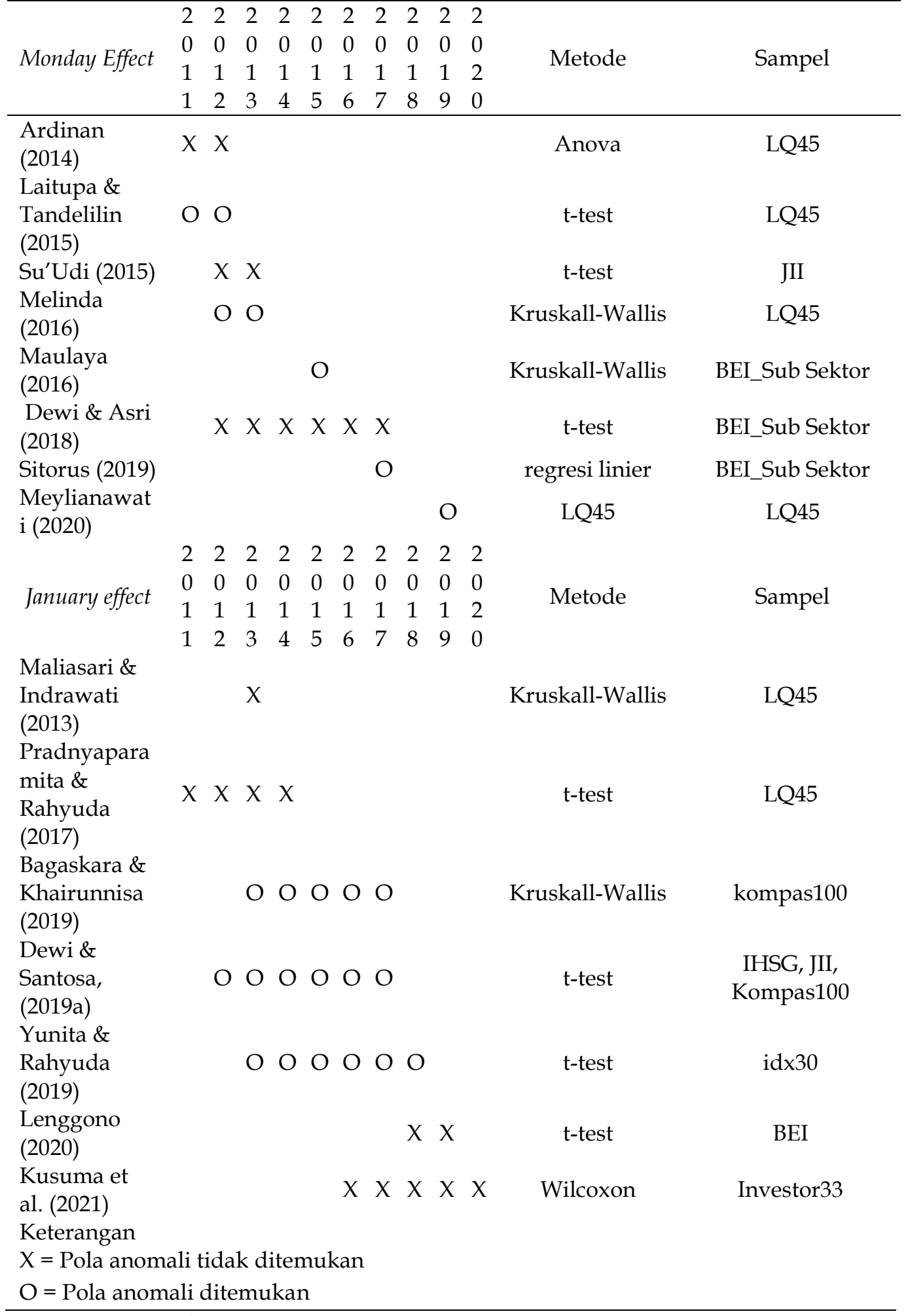

Sumber: Data Penelitian, 2021 
Monday effect merupakan fenomena anomali musiman di mana rata-rata return pada hari Senin secara signifikan lebih rendah dibandingkan rata-rata return hari perdagangan lain nya (Jaffe et al. (1989), Tandelilin (2017), Wang et al. (1997)). Anomali Monday effect pertama kali dilaporkan oleh Cross (1973). Beberapa teori dan argumen menyatakan Monday effect disebabkan oleh tendensi perusahaan merilis berita buruk pada hari Jumat malam, short selling dan penurunan optimisme dari trader selama akhir pekan. Spekulasi Singleton \& Wingender (2003) menyatakan penyebab Monday effect diakibatkan faktor ekonomi dan psikologi. Federal Reserve mengungkap pada tahun 1987 hingga 1998 Monday effect telah menghilang, namun setelah krisis ekonomi anomali ini kembali dengan peningkatan frekuensi return negatif pada hari Senin (Bernhardt \& Eckblad, 2013). Penelitian yang menemukan pola anomali ini di pasar modal Indonesia dalam sepuluh tahun terakhir antara lain Maulaya (2016), Melinda (2016), Meylianawati (2020), Rahmawati \& Hidayati (2016), Ramadhani (2016), dan Sumiyana (2008). Penelitian yang tidak menemukan pola anomali dalam sepuluh tahun terakhir antara lain Ardinan (2014), Meidona et al. (2021), Su'Udi (2015) dan Suyanto (2019).

January effect merupakan fenomena anomali musiman di mana rata-rata return pada bulan Januari secara signifikan lebih tinggi dibandingkan dengan rata-rata return bulan lainnya (Folliott, 2007). Terdapat tiga argumen populer mengenai penyebab January effect yaitu window dressing akibat penjualanpenjualan saham berkinerja buruk oleh manajer keuangan, tax-loss selling hypothesis akibat penjualan saham rugi untuk mengurangi beban pajak dan bonus akhir tahun untuk memulai investasi awal tahun. Kesulitan utama mengklasifikasi penyebab January effect adalah membedakan perdagangan individu dari perdagangan institusional, dan perdagangan yang dimotivasi pajak dari perdagangan lainnya (Park \& Moskalev, 2010). Penelitian pertama mengenai anomali ini dapat ditelusuri hingga penelitian Wachtel (1942). Beberapa penelitian berpendapat bahwa January effect masih terus ada di pasar saham meskipun telah dipublikasikan selama bertahun-tahun. Namun, penelitian lain menunjukkan bahwa January effect sudah kehilangan momentumnya di tahun-tahun terakhir. Penelitian yang menemukan pola anomali ini di pasar modal Indonesia dalam sepuluh tahun terakhir antara lain Kusuma, et al. (2021), Lenggono (2020), Maliasari \& Indrawati (2013) dan Pradnyaparamita \& Rahyuda (2017). Penelitian yang tidak menemukan pola anomali dalam sepuluh tahun terakhir antara lain Bagaskara \& Khairunnisa (2019) dan Dewi \& Santosa (2019).

Pengamatan dalam penelitian ini dilakukan pada indeks Kompas100 dimulai pada tahun 2011 hingga 2020. Indeks Kompas100 terdiri atas 100 perusahaan dengan likuiditas dan kapitalisasi yang besar. Indeks ini diperkirakan mewakiliki 70 hingga 80 persen dari total nilai kapitalisasi pasar seluruh saham yang tercatat di BEI dan menjadi acuan (benchmark) dari pergerakan pasar dan kinerja portofolio investasi di Bursa Efek Indonesia (Wikipedia, n.d.).

Kerangka berpikir terdapat pada Gambar 1. Periode dimulai pada tahun 2011 beriringan dengan berlakunya aturan baru yang memperketat keanggotaan di indeks Kompas100 dan ditutup pada tahun 2020 dimana Indonesia ditetapkan berstatus negara maju. Periode pengamatan menggambarkan kondisi pasar modal 
Indonesia pada periode transisi negara berkembang menjadi negara maju di tengah krisis ekonomi 2015.

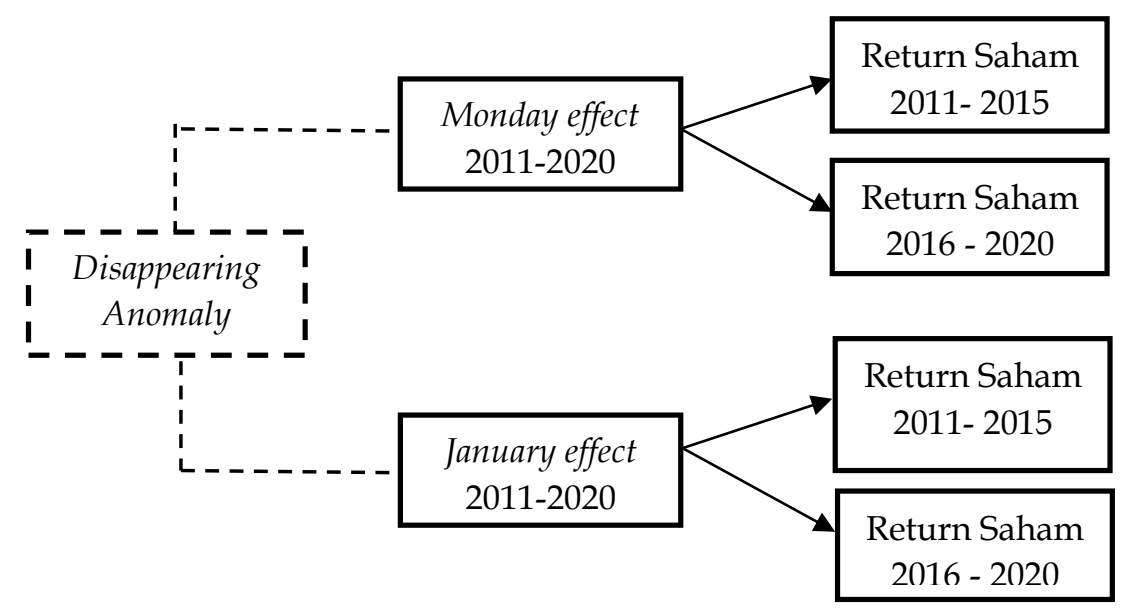

Sumber: Data Penelitian, 2021

Gambar 1. Kerangka Berpikir Penelitian

Pengamatan return saham di bagi menjadi dua kelompok data yaitu kelompok I 2011 hingga 2015 dibandingkan dengan kelompok II 2016 hingga 2020. Krisis ekonomi tahun 2015 menjadi titik pembagi dua kelompok pengamatan menjadi kelompok sebelum krisis ekonomi 2015 dan setelah krisis ekonomi 2015. Pada tahun 2015 ekonomi Indonesia mengalami tiga tekanan yaitu 1) Pasar keuangan global dimana otoritas moneter Tiongkok pada Agustus 2015 melakukan devaluasi mata uang Yuan, 2) Penarikan stimulus oleh Amerika Serikat melalui kenaikan tingkat suku bunga Bank Sentral Amerika Serikat (The Fed) dan 3) Tren penurunan harga minyak mentah dunia. Primadhyta (2015) menyimpulkan perekonomian Indonesia pada periode krisis dinyatakan mengalami ketidakpastian ekonomi yang menghambat perekonomian dan membuat pasar keuangan bergejolak (volatile) dengan tingkat yang lebih dari sebelumnya.

Selama periode pengamatan 2011 hingga 2020, terdapat fenomenafenomena yang mempengaruhi data penelitian. Salah satu fenomena yang paling berpengaruh adalah terjadinya pandemi Covid-19 di Indonesia. Pada awal pandemic dimana terjadi kepanikan pasar saham, seluruh indeks dan pertumbuhan ekonomi di Indonesia mengalami penurunan. Saraswati (2020) menemukan penurunan harga saham di semua sektor industri dengan penurunan dalam jangkauan 9,96 persen hingga 33,32 persen pada triwulan I tahun 2020. Sembel (2021, Jan 6) melaporkan pemulihan harga saham di IHSG terjadi pada triwulan II dan semakin membaik hingga triwulan IV. Pola historis return bulanan di IHSG telah dinyatakan kembali normal di tahun 2021. Untuk mengurangi bias signifikan atas fluktuasi harga yang terjadi, data-data ekstrem sudah di eliminasi sebelum melaksanakan pengujian.

Teori yang dipergunakan dalam penelitian ini adalah hipotesis pasar efisien, teori sinyal, teori perilaku keuangan dan teori siklus pasar Wyckoff. Dalam hipotesis pasar efisien terdapat tiga bentuk pasar berdasarkan penyerapan informasinya, yaitu, 1) Pasar efisien bentuk lemah dimana harga saham merefleksi 
informasi lampau secara penuh dimana harga saham bersifat random walk (harga saham lampau tidak dapat memprediksi harga saham saat ini). 2) Pasar efisien bentuk semi kuat dimana harga saham merefleksi informasi publik secara penuh seperti pengumuman laba dan dividen, merger, pemecahan saham atau pengumuman lainnya, dan 3) Pasar efisien bentuk kuat dimana harga saham merefleksi seluruh informasi yang tersedia, termasuk informasi publik dan privat. Meskipun informasi privat tidak tersedia untuk umum, informasi privat diasumsikan telah diperhitungkan. Teori sinyal menggambarkan hubungan informasi \investor pasar modal pemula di Indonesia mengalami peningkatan signifikan. Berdasarkan data KSEI, pada tahun 2020 terjadi peningkatan jumlah investor sebanyak lebih dari 50 persen dari 2.484.354 investor di akhir tahun 2019 menjadi 3.880.753 investor di akhir tahun 2020. Hasil penelitian ini diharapkan memberikan informasi yang eye-opening pada investor pemula di Indonesia terkait perubahan kondisi pasar dengan memahami histori dan melaksanakan pengambilan keputusan yang lebih baik. Tidak ada jaminan masa lalu akan terulang dan menghasilkan konsekuensi serupa, namun mengetahui dan mempersiapkan diri atas berbagai kemungkinan dapat membantu proses pengambilan keputusan lebih bijak dan menguntungkan di pasar modal yang penuh resiko.

Disappearing anomaly dilaporkan terjadi di beberapa negara maju selain Amerika Serikat, Inggris dan Singapura, yaitu Prancis, Hongkong dan Australia (Kohers et al., 2004). Cotter \& McGeever (2018) menyatakan bahwa fenomena tersebut mengindikasi adanya peningkatan efisiensi pasar. Disappearing anomaly dapat disebabkan perilaku setiap investor yang menjadi lebih rasional dan aktif menganalisis pasar modal serta kritis dalam bereaksi pada sinyal yang dikirimkan oleh perusahaan ataupun eksternal pasar. Jika sebuah informasi diinterpretasikan positif, maka permintaan atas saham akan meningkat kemudian meningkatkan harga saham tersebut. Investor sebagai penerima sinyal hanya dapat menginterpretasikan sinyal tanpa ada kepastian bahwa interpretasi dan keputusan yang diambil atas sinyal tersebut adalah tepat. Kemajuan suatu negara dengan perkembangan infrastruktur teknologi informasi dapat mempermudah dalam penyetaraan asimetri informasi dan sebagai sarana prasarana untuk mengembangkan kualitas investor. Memahami bahwa pola-pola harga saham dari pemanfaatan anomali cenderung tidak stabil dan baku mengikuti pola pergerakan harga saham sesuai teori siklus pasar Wyckoff (accumulation, spring, markup, distribution, spring markdown) sehingga memilih untuk tidak bergantung pada teknik tersebut dapat menyebabkan anomali menjadi semakin lemah. Di Indonesia, teknik pemanfaatan anomali yang telah eksis sejak awal tahun 2000 tidak lagi menjadi teknik populer dalam persaingan strategis di pasar. Investor yang 'canggih' akan mempertimbangkan pemikiran investor lain, tidak hanya menjadi 'follower' namun secara aktif menganalisis kondisi pasar serta perusahaan, memprediksi pengambilan keputusan investor mayoritas dalam pembelian saham untuk masuk lebih dulu pada saham-saham tersebut. Teknik yang telah lama dimanfaatkan tidak menjadi opsi menarik untuk dieksploitasi oleh investor yang canggih.

Hasil penelitian Monday effect pada pasar modal di Indonesia di awal tahun 2010 membuktikan masih ditemukannya anomali Monday effect pada tahun 2011 
hingga 2012 (Ardinan, 2014), tahun 2012 hingga 2013 (Su'Udi, 2015), tahun 2015 (Maulaya, 2016). Penelitian yang membuktikan ketiadaan Monday effect pada tahun 2015 hingga 2016 (Apsari, 2018) dan tahun 2016 hingga 2017 (Safitri et al., 2018).

$\mathrm{H}_{1}$ : Rata-rata Monday effect pada indeks Kompas100 periode 2016 hingga 2020 lebih rendah dibandingkan periode 2011 hingga 2015.

Anomali January effect dilaporkan terjadi pada periode 2009 hingga 2014 (Pradnyaparamita \& Rahyuda, 2017), periode 2011 hingga 2013 (Kartikasari, 2017), tahun 2013 (Maliasari \& Indrawati, 2013), periode 2016 hingga 2020 (Kusuma et al., 2021). Penelitian mengungkap tidak terjadi January effect pada tahun 2014 dan 2015 (Mutiasari \& Paramita, 2016) kemudian tahun 2017 dan 2019 (Karissanata, 2019a). Berdasarkan pola temuan tersebut, maka dirumuskan hipotesis sebagai berikut:

$\mathrm{H}_{2}$ : Rata-rata January effect pada indeks Kompas100 periode 2016 hingga 2020 lebih rendah dibandingkan periode 2011 hingga 2015.

\section{METODE PENELITIAN}

Terdapat dua variabel independen yaitu Monday effect dan January effect dan satu variabel dependen yaitu return saham pada penelitian ini. Data penelitian menggunakan data kuantitatif yaitu return saham. Monday effect di ukur sebesar selisih antara rata-rata return Non Senin terhadap Senin. January effect di ukur sebesar selisih antara rata-rata return Januari terhadap Non Januari. Return saham diukur dengan rumus $\mathrm{Pt}=\mathrm{Pt}-(\mathrm{Pt}-1) / \mathrm{Pt}-1$. Data diperoleh melalui dokumentasi pada situs BEI, Yahoo Finance, Sahamu dan SahamOK. Nilai ekstrem pada masingmasing tahun dikeluarkan dari sampel dengan pendekatan Interquartile Range Rule (IQR) untuk mengurangi bias pada data penelitian dan distorsi hasil analisis statistik. Dalam penelitian ini, Hipotesis di uji dengan membandingkan Monday effect dan January effect periode 2011 hingga 2015 dengan periode 2016 hingga 2020. Ruang lingkup penelitian ini dilaksanakan pada indeks Kompas100 yang dipandang cukup representatif untuk meneliti terjadinya fenomena disappearing anomaly. Populasi penelitian ini adalah seluruh perusahaan yang terdaftar dalam indeks Kompas100 selama periode 2011 hingga 2020. Jumlah populasi dalam penelitian ini sebanyak 224 perusahaan. Teknik pengambilan sampel dalam penelitian ini menggunakan metode purposive sampling yang memenuhi kriteria perusahaan yang konsisten terdaftar dalam indeks Kompas100 selama periode pengamatan 2011 hingga 2020. Perusahaan yang tidak terdaftar secara konsisten di Kompas100 akan dikeluarkan. Berdasarkan kriteria di atas, jumlah sampel penelitian sebanyak 42 perusahaan yang akan diamati.

Indeks Kompas100 digunakan sebagai sampel karena setiap anggota nya memiliki karakteristik likuiditas dan nilai kapitalisasi pasar yang besar, serta fundamental dan kinerja yang baik. BEI bertanggung jawab dalam pemilihan perusahaan-perusahaan yang masuk ke indeks ini dengan kriteria sebagai berikut: 1) Tercatat minimal tiga bulan di Bursa Efek Indonesia (BEI), 2) Aktivitas transaksi reguler seperti nilai, volume \& frekuensi transaksi, 3) Jumlah hari perdagangan di pasar regular dan 4) Kapitalisasi pasar pada periode waktu tertentu. Evaluasi dan pergantian saham dalam Indeks Kompas100 akan dilakukan setiap 6 bulan sekali untuk memastikan setiap anggota memenuhi kriteria yang telah ditentukan. 
Teknik analisis data menggunakan pengujian independent sample t-test. Independent sample t-test merupakan uji parametrik yang digunakan untuk mengetahui adakah perbedaan mean antara dua kelompok bebas atau dua kelompok yang tidak berpasangan. Pembuktian hipotesis dinyatakan diterima jika nilai signifikansi kurang dari 0,05.

Dalam pengujian hipotesis satu \& dua serta pengujian tahunan, penulis menjalankan Levene's test yang merupakan pengujian prasyarat dari independent sample t-test. Levene's test disebut pula uji homogenitas untuk mengetahui bahwa dua atau lebih kelompok data sampel berasal dari populasi yang memiliki varians sama dengan kriteria nilai signifikansi Levene's test lebih besar atau sama dengan 0,05. Nilai dari Levene's test menentukan asumsi dasar pada pengujian hipotesis yang menggunakan independent sample t-test.

\section{HASIL DAN PEMBAHASAN}

Sebelum pengujian hipotesis, nilai ekstrem dikeluarkan dari sampel pada empat tahapan pengolahan data yaitu 1) Return harian setiap tahun, 2) Return bulanan setiap tahun, 3) Rata-rata selisih return hari Non Senin terhadap hari Senin pada kelompok I tahun 2011 hingga 2015 serta kelompok II tahun 2016 hingga 2020 dan 4) Rata-rata selisih return bulan Januari terhadap Non Januari pada kelompok I tahun 2011 hingga 2015 serta kelompok II tahun 2016 hingga 2020. Deskripsi nilai ekstrem pengujian hipotesis disappearing Monday effect pada Tabel 2.

Tabel 2. Nilai Ekstrem Pengujian Disappearing Monday Effect

\begin{tabular}{lccccc}
\hline $\begin{array}{l}\text { Kelompok } \\
\text { Tahun }\end{array}$ & $(\mathrm{N})$ Data & $\begin{array}{c}(\mathrm{N}) \mathrm{N} . \\
\text { Ekstrem }\end{array}$ & $\begin{array}{c}\% \mathrm{~N} . \\
\text { Ekstrem }\end{array}$ & $\begin{array}{c}(\mathrm{N})> \\
\text { Batas Atas }\end{array}$ & $\begin{array}{c}(\mathrm{N})<\text { Batas } \\
\text { Bawah }\end{array}$ \\
\hline $2011-2015$ & 210 & 3 & $1,43 \%$ & 0 & 3 \\
$2016-2020$ & 210 & 1 & $0,48 \%$ & 1 & 0 \\
\hline
\end{tabular}

Sumber: Data Penelitian, 2021

Jumlah data sebanyak 210 diperoleh dari perhitungan per tahun selama lima tahun atas 42 sampel perusahaan. Dalam satu tahun terdapat satu nilai yang merupakan selisih dari rata-rata return Non Senin (52-53 data) terhadap rata-rata return Senin (52-53 data). Sehingga dalam satu tahun terdapat 42 data dan pada lima tahun terdapat 210 data. Terdapat sejumlah 3 nilai ekstrem pada periode 2011 hingga 2015 yang lebih kecil dari batas bawah dan 1 nilai ekstrem pada periode 2016 hingga 2020 yang lebih besar dari batas atas. Total jumlah nilai ekstrem adalah 4 data atau 1,91 persen dibandingkan total seluruh data. Deskripsi nilai ekstrem pengujian hipotesis disappearing January effect pada Tabel 3.

Tabel 3. Nilai Ekstrem Pengujian Disappearing January Effect

\begin{tabular}{lccccc}
\hline Kelompok Tahun & $(\mathrm{N})$ Data & $\begin{array}{c}(\mathrm{N}) \mathrm{N} . \\
\text { Ekstrem }\end{array}$ & $\begin{array}{c}\% \mathrm{~N} . \\
\text { Ekstrem }\end{array}$ & $\begin{array}{c}(\mathrm{N})> \\
\text { Batas Atas }\end{array}$ & $\begin{array}{c}(\mathrm{N})<\text { Batas } \\
\text { Bawah }\end{array}$ \\
\hline $2011-2015$ & 206 & 3 & $1,43 \%$ & 1 & 2 \\
$2016-2020$ & 189 & 6 & $2,86 \%$ & 2 & 4 \\
\hline
\end{tabular}

Sumber: Data Penelitian, 2021

Sama seperti perhitungan data pengujian hipotesis disappearing Monday effect, jumlah data pengujian disappearing January effect diperoleh dari perhitungan per tahun selama lima tahun atas 42 sampel perusahaan. Dalam satu tahun terdapat satu nilai yang merupakan selisih dari rata-rata return Januari (1 data) 
terhadap rata-rata return Non Januari (1 data). Sehingga dalam satu tahun terdapat 42 data dan pada lima tahun terdapat 210 data. Jumlah data pada Tabel 3 tidak berjumlah 210 data karena terhapus pada filtrasi nilai ekstrem ke-2 yaitu penghapusan nilai ekstrem pada return bulanan setiap tahun nya. Terdapat sejumlah 3 nilai ekstrem pada periode 2011 hingga 2015 dimana 1 nilai lebih besar dari batas atas dan 2 nilai lebih kecil dari batas bawah. pada periode 2016 hingga 2020 terdapat 6 nilai ekstrem dimana 2 nilai lebih besar dari batas atas dan 4 nilai lebih kecil dari batas bawah. Total jumlah nilai ekstrem adalah 9 data atau 4,29 persen dibandingkan total seluruh data. Ringkasan statistik deskriptif, signifikansi nilai Levene's test dan nilai signifikansi pengujian independent t-test terhadap hipotesis disappearing Monday effect periode 2011 hingga 2020 terdapat di Tabel 4 dan Tabel 5.

Tabel 4. Statistik Deskriptif Pengujian Hipotesis Disappearing Monday Effect

\begin{tabular}{ccccc}
\hline Periode & Mean & Max. & Min. & Std. Deviation \\
\hline $2011-2015$ & 0,002 & 0,008 & $-0,004$ & 0,002 \\
$2016-2020$ & 0,000 & 0,006 & $-0,004$ & 0,002 \\
\hline
\end{tabular}

Sumber: Data Penelitian, 2021

Pada periode 2011 hingga 2015 nilai rata-rata selisih return hari Non Senin terhadap Senin senilai 0,002 menunjukan rata-rata return hari Non Senin lebih besar dari rata-rata return hari Senin. Nilai selisih rata-rata return mengalami penurunan pada periode 2016 hingga 2020 senilai 0,000 menunjukan rata-rata return hari Non Senin lebih besar dari rata-rata return hari Senin mengalami penurunan. Nilai selisih return maksimal terdapat di periode 2011 hingga 2015 sedangkan nilai selisih return minimal dengan nilai yang sama akibat batasan nilai ekstrem. Nilai deviasi standar disappearing Monday effect pada periode 2011 hingga 2015 menunjukan nilai 0,002 lebih besar dibandingkan nilai rata-rata 0,002, hal ini menunjukan sebaran data pada periode 2011 hingga 2015 tidak merata. Nilai deviasi standar disappearing Monday effect pada periode 2016 hingga 2020 menunjukan nilai 0,002456 lebih besar dibandingkan nilai rata-rata 0,000, hal ini menunjukan sebaran data pada periode 2011 hingga 2015 tidak merata.

Tabel 5. Signifikansi Nilai Levene's Test $\mathcal{E}$ Pengujian Hipotesis Disappearing Monday Effect

\begin{tabular}{lllcl}
\hline & Levene's test & \multicolumn{3}{c}{ Independent t-test } \\
\hline $\mathrm{F}$ & (Sig.) & $t$ & Sig. (2-tailed) & $\begin{array}{l}\text { Mean } \\
\text { difference }\end{array}$ \\
0,038 & 0,846 & 6,773 & 0,000 & 0,001 \\
\hline
\end{tabular}

Sumber: Data Penelitian, 2021

Nilai signifikansi Levene's test 0,846 lebih besar dari 0,05 menerangkan terpenuhinya asumsi kedua varian sama (equal variance assumed). Berdasarkan hasil pengujian statistik pada Tabel 4 dan Tabel 5, terdapat selisih antara rata-rata return di hari Non Senin dengan Senin pada periode 2011 hingga 2015 jika dibandingkan dengan periode 2016 hingga 2020. Terjadi penurunan rata-rata selisih return dengan perbedaan rata-rata 0,001 serta nilai signifikansi $t$-test 0,000 di bawah 0,05 menjelaskan bahwa penurunan terjadi secara signifikan. Hasil pengujian statistik menyimpulkan terjadi disappearing Monday effect setelah krisis ekonomi 2015 pada periode pengamatan 2011 hingga 2020. Dengan demikian, maka hipotesis pertama dinyatakan diterima. 
Informasi keberadaan Monday effect telah dipublikasi secara internasional oleh Cross (1973) namun masih terjadi pada pasar modal Indonesia. Pembentukan siklus rata-rata return lebih rendah pada hari Senin dibandingkan hari Non Senin berulang terus menerus dapat menjadi sinyal yang mempengaruhi keputusan investor secara kurang rasional menjadi lebih konservatif pada hari Senin. Dalam pengujian, dinyatakan terjadi disappearing Monday effect setelah krisis ekonomi 2015. Wong, et al. (2006) berpendapat krisis ekonomi dapat menyebabkan instabilitas dan volatilitas tinggi mempengaruhi keputusan investor.

Monday effect dilaporkan terjadi pada perusahaan berkapitalisasi besar dan kecil. Singleton \& Wingender (2003) mengungkap bahwa pada perusahaan berkapitalisasi besar fenomena Monday effect telah berkurang, sedangkan pada saham berkapitalisasi kecil fenomena Monday effect masih lebih banyak dan tersebar pada seluruh periode waktu. Hal ini menjelaskan signifikansi disappearing Monday effect pada indeks Kompas100. Singleton \& Wingender berspekulasi fenomena Monday effect diasosiakan pada faktor makroekonomi yang secara teknikal berada di luar kemampuan untuk di uji dengan pasti.

Hasil penelitian terdahulu pada Tabel 6, menunjuk bahwa fenomena Monday effect lebih banyak terjadi pada periode 2011 hingga 2015 dibandingkan pada periode 2016 hingga 2020. Dengan demikian dapat dikatakan bahwa hasil penelitian ini konsisten dengan temuan penelitian sebelumnya.

Tabel 6. Daftar Penelitian Monday Effect di Pasar Modal Indonesia yang Mendukung

\begin{tabular}{|c|c|c|c|}
\hline Penulis & $\begin{array}{c}\text { Tahun } \\
\text { Pengamatan }\end{array}$ & Sampel & Hasil Pengamatan \\
\hline (Purnama, 2018) & $2010-2016$ & BEJ & Terjadi Monday effect \\
\hline (Ramadhani, 2016) & $2011-2013$ & $\begin{array}{l}\text { Indeks JII \& LQ } \\
45\end{array}$ & Terjadi Monday effect \\
\hline $\begin{array}{l}\text { (Rahmawati \& Hidayati, } \\
\text { 2016) }\end{array}$ & 2015 & LQ 45 & Terjadi Monday effect \\
\hline (Melinda, 2016) & 2015 & LQ & effect \\
\hline (Maulaya, 2016) & 2015 & LQ 45 & Terjadi $M o$ \\
\hline (Karissanata, 2019b) & 2015-2018 & LQ 45 & $\begin{array}{l}\text { Tidak terjadi Monday } \\
\text { effect }\end{array}$ \\
\hline $\begin{array}{l}\text { (Sagina \& Sulasmiyati, } \\
\text { 2017) }\end{array}$ & 201 & $\begin{array}{c}\text { Sektor } \\
\text { Pertambangan }\end{array}$ & $\begin{array}{l}\text { Tidak terjadi Monday } \\
\text { effect }\end{array}$ \\
\hline (Meylianawati, 2020) & 2019 & LQ 45 & Terjadi Monday effect \\
\hline
\end{tabular}

Sumber: Data Penelitia, 2021

Ringkasan statistik deskriptif, signifikansi nilai Levene's test dan nilai signifikansi pengujian independent $t$-test terhadap hipotesis disappearing January effect periode 2011 hingga 2020 terdapat di Tabel 7 dan Tabel 8.

Tabel 7. Statistik Deskriptif Pengujian Hipotesis Disappearing January Effect

\begin{tabular}{ccccc}
\hline Periode & Mean & Max. & Min. & Std. Deviation \\
\hline $2011-2015$ & 0,000 & 0,010 & $-0,011$ & 0,004 \\
$2016-2020$ & 0,000 & 0,010 & $-0,011$ & 0,004 \\
\hline
\end{tabular}

Pada periode 2011 hingga 2015 memiliki rata-rata selisih bulan Januari terhadap Non Januari senilai 0,000bmenunjukan rata-rata return bulan Januari tidak lebih besar atau lebih kecil dari rata-rata return bulan Non Januari. Nilai ratarata selisih Januari terhadap Non Januari stagnan pada periode 2016 hingga 2020 
senilai 0,000. Nilai selisih return maksimal dan minimal atas disappearing January effect di periode 2011 hingga 2015 dengan 2016 hingga 2020 tidak terdapat perbedaan signifikan. Nilai deviasi standar disappearing January effect pada periode 2011 hingga 2015 serta periode 2016 hingga 2020 menunjukan nilai 0,004 lebih besar dibandingkan nilai rata-rata 0,000, hal ini menunjukan bahwa sebaran data pada periode 2011 hingga 2015 tidak merata.

Tabel 8. Signifikansi Nilai Levene's Test \& Pengujian Hipotesis Disappearing January Effect

\begin{tabular}{lclll}
\hline & Levene's test & \multicolumn{3}{c}{ Independent $t$-test } \\
\hline $\mathrm{F}$ & (Sig.) & $t$ & Sig. (2-tailed) & Mean difference \\
0,355 & 0,552 & 1,133 & 0,257 & 0,000 \\
\hline
\end{tabular}

Nilai signifikansi Levene's test sebesar 0,552 lebih besar dari 0,05 menerangkan terpenuhinya asumsi kedua varian sama (equal variance assumed). Berdasarkan hasil pengujian statistik pada Tabel 7 dan Tabel 8, tidak terdapat selisih antara rata-rata return di bulan Januari dengan Non Januari pada periode 2011 hingga 2015 jika dibandingkan dengan periode 2016 hingga 2020. Nilai signifikansi $t$-test $0,257>0,05$ menjelaskan bahwa perbandingan January effect pada kedua periode terjadi secara tidak signifikan. Hasil pengujian secara statistik menyimpulkan tidak terjadi disappearing January effect setelah krisis ekonomi 2015 pada periode pengamatan 2011 hingga 2020. Dengan demikian, maka hipotesis kedua dinyatakan ditolak.

Tabel 9. Pengujian Tambahan One Sample t-test atas Hipotaesis Dua

\begin{tabular}{cccc}
\hline Periode & $t$ & Sig. (2-tailed) & Mean difference \\
\hline $2011-2015$ & 0,199 & 0,843 & 0,000 \\
$2016-2020$ & $-1,338$ & 0,182 & 0,000 \\
\hline
\end{tabular}

Dalam pengujian tambahan atas penolakan hipotesis kedua dengan menggunakan one sample t-test diperoleh hasil bahwa baik pada periode 2011 hingga 2015 dan periode 2016 hingga 2020, signifikansi terjadi nya January effect lebih besar dari 0,05. pada periode 2011 hingga 2015 nilai signifikansi senilai 0,843 lebih besar dari 0,05 dan pada periode 2016 hingga 2020 nilai signifikansi senilai 0,182 lebih besar dari 0,05. Terdapat kemungkinan bahwa January effect telah menghilang sejak awal periode pengamatan.

\section{SIMPULAN}

Penelitian ini menguji disappearing Monday effect dan January effect pada indeks Kompas100 selama periode 2011 hingga 2020 dengan krisis ekonomi tahun 2015 sebagai titik pembagi dua periode pengamatan. Hipotesis pertama diterima. Pengujian statistik membuktikan rata-rata Monday effect pada indeks Kompas100periode 2016 hingga 2020 secara signifikan lebih rendah dibandingkan periode 2011 hingga 2015 sehingga disimpulkan terjadi disappearing Monday effect pada indeks Kompas100. Pengujian hipotesis kedua ditolak, pengujian statistik tidak membuktikan rata-rata January effect pada indeks Kompas100 periode 2016 hingga 2020 secara signifikan lebih rendah dibandingkan periode 2011 hingga 2015 sehingga disimpulkan tidak terjadi disappearing January effect pada indeks Kompas100. Penolakan atas hipotesis kedua kemungkinan disebabkan karena January effect sebenarnya telah menghilang sejak awal periode pengamatan. Hasil 
pengujian tambahan dengan one sample $t$-test menunjukan tingkat signifikansi sebesar 0,843 (tidak signifikan) untuk periode 2011 hingga 2015 dan sebesar 0,182 (tidak signifikan) untuk periode 2016-2020.

Para investor di pasar modal Indonesia disarankan untuk tidak bertransaksi berdasarkan Monday effect dan January effect karena terindikasi bahwa keberadaannya telah melemah bahkan menghilang di pasar modal Indonesia. Penelitian lanjutan dapat dilakukan untuk mengkaji keberadaan January effect sebelum tahun 2011. Kekurangan penelitian ini terdapat pada kredibilitas data tahun 2020 dimana harga saham pada triwulan I mengalami penurunan menyeluruh akibat kepanikan pasar saham atas pandemi Covid-19, untuk mengurangi bias dari fenomena ini dilaksanakan penghapusan nilai ekstrem pada return saham setiap tahun nya.

\section{REFERENSI}

Al-Smadi, A. A. A., Almsafir, M. K., \& Binti Husni, N. H. H. (2018). Trends and calendar effects in Malaysia's stock market. Romanian Economic and Business Review, 6(1), 15-22. https:// doi.org/10.5430/ijhe.v6n1p18

Ardinan, H. (2014). Pengujian Monday effect pada Bursa Efek Indonesia dan Bursa Efek Singapura. Journal of Business and Banking, 4(1), 81-90. https://doi.org/10.14414/jbb.v4i1.295

Bagaskara, W., \& Khairunnisa, K. (2019). Market anomaly analysis: the day of the week effect, january effect, rogalsky effect and weekfour effect testing in Indonesia Stock Exchange (Case Study on Companies Listed in Lq45 Index in 2013- 2017). Accruals, 3(1), 83-91. https:/ / doi.org/10.35310/accruals.v3i1.42

Bernhardt, D., \& Eckblad, M. (2013). Stock market crash of 1987. Federal Reserve Bank of Chicago. https://www.federalreservehistory.org/essays/stock_market_crash_of_198 7

Cotter, J., \& McGeever, N. (2018). Are Equity market anomalies disappearing? Evidence from the U.K. SSRN Electronic Journal. https://doi.org/10.2139/ssrn.3102563

Dewi, D. Y., \& Santosa, P. W. (2019). Does the january effect anomaly still exist at indonesia stock exchange? The International Journal of Business Management and Technology, $3(6)$,

http://www.theijbmt.com/archive/0930/964895022.pdf

Dewi, P. C., \& Asri, M. (2018). Monday effect pada pengumuman dividen naik dan dividen turun di Bursa Efek Indonesia tahun 2012-2017 [Undergraduate Thesis, Gadjah Mada University]. UGM Repository. http:/ / etd.repository.ugm.ac.id/home/detail_pencarian/160987

Fama, E. F. (1970). Session topic: stock market price behavior session chairman: burton g. malkiel efficient capital markets: A Review Of Theory And Empirical Work. The Journal of Finance, 25(2), 383-417.

Folliott, T. (2007). the January Effect: a global perspective. [Master Thesis, Simon Fraser University]. Simon Repository. http://summit.sfu.ca/item/8323

Jaffe, J. F., Westerfield, R., \& Ma, C. (1989). A twist on the monday effect in stock prices. Evidence from the U.S. and foreign stock markets. Journal of Banking and Finance, 13(4-5), 641-650. https:// doi.org/10.1016/0378-4266(89)90035-6 
Karissanata, N. C. (2019). Analisis pengaruh fenomena january effect dan monday effect pada return perusahaan yang terdaftar sebagai indeks lq-45 di bursa efek indonesia periode 2015-2018. [Undergraduate Thesis, Islam Indonesia University]. Islam Indonesia

Repository. https://dspace.uii.ac.id/bitstream/handle/123456789/16100/15311309.pdf ?sequence $=13 \&$ is 1 llowed $=y$

Kartikasari, L. H. (2017). Pengujian january effect: studi komparasi pada bursa efek idonesia dan bursa saham shanghai periode 2011-2013. Journal of Business and Banking, 6(1), 65-80. https:/ / doi.org/10.14414/jbb.v6i1.657

Kohers, G., Kohers, N., Pandey, V., \& Kohers, T. (2004). The disappearing day-ofthe-week effect in the world's largest equity markets. Applied Economics Letters, 11(3), 167-171. https:// doi.org/10.1080/1350485042000203797

Kusuma, M. B., Yanuar, \& Cicilia. (2021). January effect on the Indonesian Stock Market. International Journal of Research Publications, 70(1), 35-45. https://doi.org/10.47119/ijrp100701220211714

Lenggono, T. O. (2020). Pengaruh january effect terhadap abnormal return saham. Cita Ekonomika, XIV(2), 111-121. https://ojs3.unpatti.ac.id/index.php/citaekonomika/article/view/2729

Maliasari, K., \& Indrawati, N. K. (2013). Pengaruh january effect dan rogalski effect terhadap abnormal return saham dan trading volume activity. Jurnal Ilmiah Mahasiswa FEB Universitas Brawijaya, 2(2), 1-2. https://jimfeb.ub.ac.id/index.php/jimfeb/article/view/1153

Marquering, W., Nisser, J., \& Valla, T. (2006). Disappearing anomalies: A dynamic analysis of the persistence of anomalies. Applied Financial Economics, 16(4), 291-302. https:/ / doi.org/10.1080/09603100500400361

Maulaya, W. G. (2016). Pengujian fenomena monday effect dan week four effect terhadap return saham pada perusahaan property dan real estate yang terdaftar Di BEI tahun 2015. [Undergraduate Thesis, STIE Surabaya]. http://eprints.perbanas.ac.id/1822/

Meidona, S., Multama, I., \& Saputri, R. (2021). Analisis fenomena the monday effect pada return harian saham perusahaan industri pengolahan yang terdaftar Di Bursa Efek Indonesia Periode 2019. 1(1), 47-61. https://ojs.iainbatusangkar.ac.id/ojs/index.php/jaksya/article/view/2743

Melinda, V. (2016). Pengujian fenomena anomali pasar the monday effect pada perusahaan ( the examination of monday effect market aanomalous phenomenon on the company $l q 45$ ). [Undergraduate Thesis, Jember University]. UNEJ Repository.

https://repository.unej.ac.id/bitstream/handle/123456789/81919

Meylianawati, F. (2021, Agustus). Analisis hari perdagangan, monday effect, weekend effect, dan rogalsky effect terhadap return saham (studi pada perusahaan LQ 45 di Bursa Efek Indonesia periode februari 2019 - januari 2020 ). Business and Economics Conference in Utilization of Modern Technology, Magelang. 670 - 689.

Mutiasari, D., \& Paramita, V. S. (2016). Analisis january effect pada return saham, abnormal return dan trading volume activity untuk kelompok saham indeks LQ-45 di Bursa Efek Indonesia (BEI) Tahun 2013-2016. Working Papers Series In Management, Yogyakarta, 131-143. 
Park, S.-C., \& Moskalev, S. A. (2010). The 52-week high and the january effect. Journal of Business $\mathcal{E}$ Economics Research (JBER), 8(3), 43-58. https://doi.org/10.19030/jber.v8i3.688

Pradnyaparamita, N. M. W., \& Rahyuda, H. (2017). Pengujian anomali pasar january effect pada perusahaan lq45 di Bursa Efek Indonesia. E-Jurnal Manajemen Universitas Udayana, 6(7), 3513-3539. https://doi.org/10.24843/EJMUNUD.2019.v08.i09.p11

Primadhyta, S. (2015, September 21). Menkeu: gejolak ekonomi 2015 hanya eksperimen bukan krisis. CNN Indonesia. https://www.cnnindonesia.com/ekonomi/20150921125747-7880025/ menkeu-gejolak-ekonomi-2015-hanya-eksperimen-bukan-krisis

Purnama, M. (2018). Anomali monday effect pada Bursa Efek Indonesia. Primanomics: Jurnal Ekonomi dan Bisnis, 16(3), 1-13. https://jurnal.ubd.ac.id/index.php/ds

Rahmawati, S., \& Hidayati, L. N. (2016). Analisis monday effect dan weekend effect pada return saham perusahaan $L Q 45$ di Bursa Efek Indonesia. [Undergraduate Thesis, Yogyakarta State University]. UNY Repository. http://eprints.uny.ac.id/id/eprint/39139

Ramadhani, R. (2016). Pengujian anomali pasar monday effect, weekend effect, rogalski effect di bursa efek Indonesia. Jurnal Ilmiah Mahasiswa FEB Universitas $\begin{array}{llll}\text { Brawijaya, } & 3(2) . & - & 109\end{array}$ https://jimfeb.ub.ac.id/index.php/jimfeb/article/view/1690

Saraswati, H. (2020). Dampak pandemi covid-19 terhadap pasar saham di Indonesia. Jurnal Riset Akuntansi dan Keuangan Dewantara, 3(2), 153-163. https:// ejournal.stiedewantara.ac.id/index.php/JAD/article/view/696

Sagina, C., \& Sulasmiyati, S. (2017). Analisis the day of the week effect dan monday effect pasar modal (studi pada indeks sektor pertambangan bursa efek indonesia (bei) di tahun 2016). Jurnal Administrasi Bisnis (JAB), 50(2), 142-151. http://administrasibisnis.studentjournal.ub.ac.id/index.php/jab/article/vi ew/1987

Singleton, J. C., \& Wingender, J. R. (2003). The monday effect: a disaggregation Analysis. Quarterly Journal of Business E Economics, 42(January 2003), 91-112. https://www.researchgate.net/publication/272681501_The_Monday_Effect _A_Disaggregation_Analysis

Sitorus, E. H. (2019). Pengaruh monday effect, friday effect dan week-four effect terhadap return saham pada perusahaan sub sektor makanan dan minuman yang terdaftar di bursa efek indonesia. [Undergraduate Thesis, North Sumatera University]. USU Repository. https:/ / repositori.usu.ac.id/handle/123456789/12731

Su'Udi, A. A. (2015). Analisis monday effect, weekend effect, dan week four effect terhadap return saham perusahaan yang terdaftar di jii periode 2012-2013. [Undergraduate Thesis, Universtas Islam Negeri]. UIN Repository. https://digilib.uin-suka.ac.id/id/eprint/17193/

Sudirman, I. M. S. N., \& Sudirman, I. W. (2019, Mei). Evolusi day-of-the-weekeffect di pasar modal indonesia. Seminar Nasional Hasil Penelitian-Denpasar, 190-208.

Sumiyana. (2008). Day of the week dan monday effect: fenomena yang terbuktikan tidak konsisten di pasar modal indonesia. Jurnal Manajemen Teori dan Teraoan, 
1(1), 1-30. https:/ / e-journal.unair.ac.id/JMTT/article/view/ 2359

Suyanto, D. (2019). Pengujian efek hari dalam seminggu terhadap return saham perusahaan sektor industri perbankan di bursa efek indonesia. Jurnal Vokasi Indonesia, 7(1), 39-47. https://doi.org/10.7454/jvi.v7i1.140

Tversky, A., \& Kahneman, D. (1987). Judgment under uncertainty: Heuristics and Biases. Science, 185(4157), 1124-1131. https://doi.org/10.1126/ science.185.4157.1124

Wang, K., Li, Y., \& Erickson, J. (1997). American finance association a new look at the monday effect. The Journal of Finance, 52(5) (Dec, 1997 ). 2171-2186. https://doi.org/10.1111/j.1540-6261.1997.tb00412.x

Wiarta, I., daniyanti, D., \& Etriya. (2020). Anomali return pada pasar modal indonesia (studi pada bank bumn di bursa efek indonesia). Jurnal Development, 8(1), 152-157. https://doi.org/10.53978/jd.v8i2.158

Indeks Kompas100. (2021, November 23). In Wikipedia. https://id.wikipedia.org/wiki/Indeks_Kompas100

Wong, W.-K., Agarwal, A., \& Wong, N.-T. (2006). The disappearing calendar anomalies in the singapore stock market. The Lahore Journal of Economics, 11(2), 123-139. https:/ / doi.org/10.35536/lje.2006.v11.i2.a7

Yunita, N. K. E., \& Rahyuda, H. (2019). Pengujian anomali pasar (january effect) di bursa efek indonesia. E-Jurnal Manajemen Universitas Udayana, 8(9), 5571. https:// doi.org/10.24843/ ejmunud.2019.v08.i09.p11

Zaremba, A., Kizys, R., \& Raza, M. W. (2020). The long-run reversal in the long run: insights from two centuries of international equity returns. Journal of Empirical Finance, 55, 177-199. https://doi.org/10.1016/j.jempfin.2019.11.007 